\title{
Meningkatkan Keterampilan Menulis Surat Resmi dengan Menggunakan Model Pembelajaran Inkuiri Siswa Kelas VII SMP Negeri 18 Tidore Kepulauan
}

\author{
Sasmayunita \\ Universitas Khairun Ternate \\ mrsasmayunita@yahoo.com
}

\begin{abstract}
Abstrak
Penelitian ini bertujuan untuk melakukan perbaikan pembelajaran guna mengatasi kesenjangan yang terjadi dan meningkatkan hasil belajar siswa dalam pembelajaran menulis surat resmi dengan menerapkan pendekatan atau model pembelajaran Inkuiri. Peneltian ini menggunakan metode deskriptif kuantitatif. Pengambilan data dilakukan denganmmelihat populasi dan sampel. Penelitian ini mendapati hasil bahwa guru telah melakukan proses pembelajaran dengan baik sesuai dengan materi pembelajaran menulis surat resmi dengan metode atau model pembelajaran yang tepat. Berdasarkan tabel rekapitulasi hasil penilaian dalam pembelajaran menulis surat resmi siswa kelas VII SMP Negeri 18 Tidore Kepulauan dengan menggunakan 5 aspek penilaian yang telah diuraiakan di atas. Nilai yang diperoleh siswa pada tes awal (PreTest) siswa belum mencapai peningkatan nilai dalam menulis surat resmi nilai yang dicapai 52, belum mencukupi KKM sekolah, sehingga peneliti akan melakukan penelitian lanjutan untuk meningkatkan nilai yang diperoleh siswa pada tes awal (PreTest).Dari hasil tes akhir (PostTest) peneliti bisa katakan para siswa mampu menulis surat resmi dengan menggunakan model pembelajaran inkuiri. Hal ini bisa dilihat pada tabel yaitu rekapitulasi hasil penilaian, mereka bisa memperoleh nilai yang maksimal karena sebagian besar siswa mampuh mencapai (KKM) yang telah ditetapkan pada SMP Negeri 18 Tidore Kepulauan dalam pembelajaran Bahasa Indonesia dengan materi menulis surat resmi dan siswa yang mencapai (KKM) berjumlah sebanyak 17 siswa sedangkan yang tidak mencapai (KKM) berjumlah sebanyak 5 siswa yang tidak tuntas.
\end{abstract}

Kata Kunci: Surat Resmi, Inquiri, Pembelajaran

\section{Pendahuluan}

Menulis merupakan suatu proses mengungkapkan ide-ide atau gagasan, pikiran, pengalaman, dan perasaan dengan menggunakan bahasa sebagai medianya. Hal-hal yang dikemukakan dalam tulisan dapat bersumber dari pengalaman pribadi, pengalaman orang lain, atau dari membaca buku. Menulis sebagaimana berbicara, merupakan keterampilan berbahasa yang produktif dan ekspresif. Kegiatan menulis merupakan suatu keterampilan berbahasa yang dapat dipergunakan untuk berkomunikasi secara tidak langsung, tidak secara tatap muka dengan orang lain, sedangkan berbicara merupakan komunikasi tatap muka secara langsung (Tarigan, 2000: 2-3).

Menurut Nanik dkk., (2014: 64-65) surat resmi adalah surat yang berisi masalah kedinasan atau bisnis tertentu. Oleh karena itu, pembuatan surat-surat resmi merupakan bagian dari pekerjaan administratif yang penting. Sebagai salah satu bentuk komunikasi 
yang dilakukan secara tertulis, surat resmi memiliki aturan atau format yang tidak jauh berbeda dari kegiatan komunikasi lainnya. Surat dapat dikatakan efektif apabila pesan yang dituliskan oleh penulis sesuai dengan tujuannya. Dengan kata lain, pesan yang dikirimkan penulis atau lembaga dari salah satu instansi dapat dipahami, diterima, dan direspons oleh pembaca sesuai dengan yang diharapkan. Hal tersebut dapat terjadi bila isi surat dirumuskan dengan baik sesuai dengan format penulisan, serta menggunakan bahasa yang baik dan benar agar pembaca terhindar dari kesalahan penafsiran.

Dari hasil pengamatan atau observasi awal, guru bidang studi bahasa Indonesia di kelas VII pada 20 November 2019 lalu, dapat disimpulkan bahwa pada saat guru menerangkan materi tentang menulis surat resmi, sebagian besar siswa tidak memperhatikan penjelasan dari guru, siswa tidak bertanya pada saat guru memberikan kesempatan bertanya sehingga materi yang diajarkan tidak semua siswa memahaminya. Sedangkan dari hasil wawancara peneliti dengan guru bidang studi bahasa Indonesia kelas VII SMP Negeri 18 Tidore Kepulauan peneliti mendapatkan informasi bahwa pembelajara keterampilan menulis belum menggunakan model pembelajaran seperti inkuiri. Selain itu, pendekatan yang dilakukan oleh guru adalah pendekatan konvensional, yaitu pembelajaran yang masih berpusat pada guru dan siswa yang belajar lebih menitikberatkan pada hafalan, sehingga pemahaman siswa tentang cara menulis surat resmi sangat terbatas atau rendah.

Hal ini menyebabkan siswa belum mampu menulis surat resmi dengan benar dan sesuai dengan syarat-syarat penulisan surat resmi, sehingga dari hasil evaluasi materi tersebut dari 22 siswa, yang mencapai nilai di atas Kriteria Ketuntasan Minimum (KKM) 75 hanya 5 siswa (16,66\%). Oleh karena itu, guru harus melakukan perbaikan pembelajaran, memilih pendekatan atau model pembelajaran yang baik dan bervariasi sesuai dengan materi yang diajarkan agar siswa termotivasi dalam belajar yang lebih bermakna. Permasalahan tersebut sesuai dengan pendapat yang dikemukakan Hakim (2016) bahwa kemampuan tenaga pengajar dapat ditingkatkan melalui pelatihanpelatihan atau melakukan penelitian dengan merancang metode atau pendekatan yang sesuai dengan permasalahan yang dihadapi oleh peserta didik.

Untuk membentuk cara berpikir siswa secara saintifik maka diperlukan metode saintifik. Dalam hal ini strategi belajar yang tidak mengharuskan siswa menghafal faktafakta tetapi sebuah strategi pembelajaran yang mendorong siswa agar dapat mengaplikasikan pengetahuan di benak mereka sendiri. Melalui proses mengamati, bertanya, menalar, mencari dan menyelidiki informasi secara sistematis, kritis, logis dan analitis.

Mencermati masalah di atas, maka peneliti melakukan perbaikan pembelajaran yang bermakna dengan alasan, untuk mengatasi kesenjangan yang terjadi dan meningkatkan hasil belajar siswa dalam pembelajaran menulis surat resmi tersebut dan diperlukan suatu tindakan yang tepat. Salah satu pendekatan atau model pembelajaran yang cocok untuk mengatasi kesenjangan di atas dalam hal ini menulis surat resmi adalah dengan menerapkan pendekatan atau model pembelajaran Inkuiri.

Model pembelajaran inkuiri merupakan salah satu model pembelajaran yang menitikberatkan kepada aktifitas siswa dalam proses belajar. Siswa melakukan kegiatan, mengumpulkan dan menganalisis data, sampai akhirnya siswa menemukan jawaban dari 
pertanyaan itu. Model inkuiri berarti suatu rangkaian kegiatan belajar yang melibatkan secara maksimal seluruh kemampuan siswa untuk mencari dan menyelidiki secara sistematis, kritis, logis, analitis, sehingga siswa dapat merumuskan sendiri penemuannya dengan penuh percaya diri (Gulo, 2005: 84). Pendapat yang sama dikemukakan Nurhadi (2003) bahwa siswa bekerja sesuai dengan permasalahan yang sama dan bahkan mereka bekerja sama mencari solusi terhadap masalah-masalah. Setiap siswa memainkan dan memfungsikan talentanya masing-masing. Olehnya itu, pembelajaran dirancang dengan menarik dan memberikan tantangan kepada siswa agar dapat menemukan sendiri konsep yang baru (Suyatno, 2007).

Selain penerapan model pembelajaran yang digunakan untuk memperbaiki kualitas pembelajaran menulis surat resmi, peneliti juga menggunakan salah satu jenis penelitian yang sesuai dengan model pembelajaran tersebut yaitu jenis penelitian deskriptif kuantitatif. Penelitian ini dilakukan untuk memperbaiki dan meningkatkan kualitas pembelajaran yang dilaksanakan guru demi tercapainya tujuan pembelajaran menulis surat resmi sebagai sarana pengembangan penalaran, memperbaiki dan meningkatkan kinerja-kinerja pembelajaran yang dilaksanakan, mengidentifikasi, menemukan solusi, dan mengatasi masalah pembelajaran di kelas.

Berbagai hasil penelitian tentang menulis surat resmi dan penerapan pendekatan inkuiri, seperti yang dilakukan Syahfitri (2018) tentang penggunaan metode inkuiri dalam menulis surat resmi pada siswa SMP. Jenis penelitian yang digunakan ialah eksperimen. Hasil penelitian menunjukkan bahwa penggunaan metode inkuiri lebih efektif dibandingkan metode konvensional. Hasil uji statistic juga menunjukkan bahwa nilai $\mathrm{t}_{\mathrm{o}}=8,35$ pada taraf signifikansi $5 \%$ maupun $1 \%$ dengan $\mathrm{dk}=\left(\mathrm{N}_{1}-\mathrm{N}_{2}\right)$ ternyata $\mathrm{t}_{\mathrm{o}}$ yang diperoleh lebih besar dari $t_{t}$ yaitu 2,00 $<8,35>2,66$ sehingga hipotesis nol ditolak dan hipotesis alternatif diterima. Hasil penelitian yang lain tentang penerapan metode inkuiri dilakukan oleh Sugiartanti (2020) melalui penelitian tindakan kelas dalam pembelajaran menulis teks berita menggunakan model pembelajaran inkuiri. Hasil penelitian menunjukkan bahwa aktivitas siswa dalam menemukan unsur-unsur berita terjadi peningkatan seperti (mengerjakan LKS, berdiskusi, dan merespon pertanyaan teman dalam satu kelompok maupun oleh kelompok lain). Selain itu, peningkatan persentase nilai siswa yang telah mencapai KKM pada siklus I $(68,8$ $\%)$, siklus II (81,3\%), siklus III mencapai (100\%).

Berdasarkan uraian di atas, maka peneliti mengadakan penelitian dengan judul "Meningkatkan Keterampilan Menulis Surat Resmi dengan Menggunakan Model Pembelajaran Inkuiri Siswa Kelas VII SMP Negeri 18 Tidore Kepulauan."

\section{Metode}

Metode penelitian yang digunakan dalam penelitian ini adalah metode deskriptif kuantitatif, yaitu data yang dianalisis dengan menggunakan rumus peresentase berupa angka dan data statistik.

\section{Desain Penelitian}

\section{$01 \times 02$}




\section{Keterangan:}

01: Tes awal (Pretest) untuk mengukur kemampuan siswa dalam menulis surat resmi

X : Model Pembelajaran Inkuiri

02 : Teks akhir(Posttest) untuk meningkatkan kemampuan siswa dalam menulis teks berita

\section{Populasi dan Sampel}

\section{Populasi}

Menurut (Arikunto, 2013) populasi adalah keseluruhan subjek penelitian. Apabila seseorang ingin meneliti semua eleman yang ada dalam wilayah penelitian, maka penelitiannya merupakan penelitian populasi. Maka populasi dalam penelitian ini adalah seluruh siswa kelas VII SMP Negeri 18 Tidore Kepulauan yang berjumlah 22 orang siswa yang terdiri dari satu kelas.

\section{Sampel}

Sampel dalam penelitian ini yaitu ditetapkan 100\% yakni 22 siswa kelas VII sebagaimana (Arikunto, 2013) mengisyaratkan bahwa populasi kurang dari 100 orang, maka sampel dapat diambil secara keseluruhan dari populasi, namun bila populasi lebih dari 100 maka sampel lebih baik diambil dari sebagian populasi $10-15 \%$ atau $20-25 \%$.

\section{Teknik Analisis Data}

Teknik analisis yang digunakan adalah teknik analisis deskriptif kuntitatif. Analisis data kuantitatif dilakukan dengan cara menghitung data kuantutatif berdasarkan hasil penelitian yang diperoleh dari hasil menulis surat resmi dengan menggunakan model pembelajaran inkuiri.

Berdasarkan penjelasan diatas, maka rumus yang akan digunakan peneliti dalam menganalisis hasil penelitian dalam pembelajaran menulis surat resmi yaitu :

$$
\mathbf{P}=\frac{\mathbf{F}}{\mathrm{N}} \times 100 \%
$$

Keterangan :

P :Presentase

$\mathrm{F} \quad$ :Frekuensi yang diobservasi

$\mathrm{N} \quad$ :Jumlahresponden

$100 \%$ :Bilangan tetap

Untuk menghitung skor mentah menjadi nilai akhir maka peneliti menggunakan skala interval. 


\section{Hasil}

Hasil penelitian diperoleh dari hasil tes awal dalam menulis surat resmi tidak menggunakan model pembelajaran inkuiri sedangkan pada tes akhir dalam menulis surat resmi dengan menggunakan model pembelajaran inkuiri. Hasil tes disajikan dalam bentuk data kuantitatif. Pada tes awal peneliti sajikan nilai rata-rata dalam menulis surat resmi tanpa menggunakan model pembelajaran inkuiri sebagai tes awal dan selanjutnya adalah nilai rata-rata pada tes akhir peneliti menggunakan model pembeljaraninkuiri sebagai tes akhir.

\section{Hasil Rekapitulasi Nilai Pada PreTest}

\begin{tabular}{|c|c|c|c|c|c|c|c|c|c|}
\hline \multirow{2}{*}{ No } & \multirow[t]{2}{*}{ Nama Siswa } & \multicolumn{5}{|c|}{ Aspek Yang Dinilai } & \multirow{2}{*}{ Jml } & \multirow{2}{*}{ Nilai } & \multirow{2}{*}{ Ket } \\
\hline & & 1 & 2 & 3 & 4 & 5 & & & \\
\hline 1 & $\mathrm{Hd}$ & 3 & 1 & 1 & 2 & 2 & 9 & 36 & SK \\
\hline 2 & FD & 3 & 2 & 3 & 1 & 3 & 12 & 48 & SK \\
\hline 3 & AS & 2 & 4 & 1 & 1 & 2 & 10 & 40 & SK \\
\hline 4 & GK & 4 & 5 & 5 & 5 & 5 & 24 & 96 & SB \\
\hline 5 & IA & 1 & 1 & 2 & 1 & 2 & 7 & 28 & SK \\
\hline 6 & SA & 3 & 1 & 3 & 2 & 3 & 12 & 48 & SK \\
\hline 7 & FU & 1 & 3 & 2 & 3 & 1 & 10 & 40 & SK \\
\hline 8 & WG & 2 & 2 & 2 & 1 & 1 & 8 & 32 & SK \\
\hline 9 & $\mathrm{MF}$ & 3 & 1 & 3 & 3 & 2 & 12 & 48 & SK \\
\hline 10 & NK & 3 & 1 & 2 & 2 & 3 & 11 & 44 & SK \\
\hline 11 & AW & 5 & 5 & 4 & 5 & 5 & 24 & 96 & SB \\
\hline 12 & WM & 4 & 4 & 5 & 5 & 5 & 23 & 92 & SB \\
\hline 13 & FU & 2 & 2 & 2 & 1 & 3 & 10 & 40 & SK \\
\hline 14 & $\mathrm{AD}$ & 2 & 2 & 3 & 1 & 2 & 10 & 40 & SK \\
\hline 15 & $\mathrm{AB}$ & 1 & 3 & 2 & 2 & 2 & 10 & 40 & SK \\
\hline 16 & SS & 5 & 5 & 4 & 5 & 5 & 24 & 96 & SB \\
\hline 17 & RA & 2 & 4 & 1 & 4 & 1 & 12 & 48 & SK \\
\hline 18 & $\mathrm{AY}$ & 2 & 2 & 2 & 1 & 1 & 8 & 32 & SK \\
\hline 19 & MR & 2 & 1 & 2 & 3 & 1 & 9 & 36 & SK \\
\hline 20 & $\mathrm{IH}$ & 3 & 3 & 1 & 1 & 2 & 10 & 40 & SK \\
\hline 21 & DS & 2 & 1 & 2 & 1 & 2 & 8 & 32 & SK \\
\hline \multirow[t]{3}{*}{22} & $\mathrm{AH}$ & 5 & 5 & 5 & 4 & 4 & 23 & 92 & SB \\
\hline & Jumlah & 60 & 58 & 57 & 54 & 57 & 289 & 1.144 & \\
\hline & Rata-rata & 2,72 & 2,63 & 2,59 & 2,45 & 2,59 & 13,13 & 52 & \\
\hline
\end{tabular}

Dari uraian pada tabel di atas, penilaian dari lima aspek dalam rubrik penilaian sebagai aspek penilaian analisis data pada tes awal : aspek 1) bagian-bagian yang ada dalam surat resmi, 2) kelengkapan dalam kepala surat, 3) syarat penyusunan dalam membuat surat resmi, 4) kelengkapan dalam bagian penutup surat, 5) membuat surat resmi sesuai dengan struktur sistematika penulisan surat resmi yang baik dan benar. Meningkatkan keterampilan menulis surat resmi dengan menggunakan model pembelajaran inkuiri siswa kelas VII SMP Negeri 18 Tidore kepulauan, dari hasil penilaian tersebut dapat diklasifikasikan analisis data hasil penelitian, bahwa pada tes awal ada 5 siswa yang mencapai KKM dan 17 siswa belum mencapai KKM maka peneliti dapat 
simpulkan bahwa banyak siswa belum mampu menulis surat resmi karena belum tercapainya (KKM).

Hasil Rekapitulasi Nilai Pada Post Test

\begin{tabular}{|c|c|c|c|c|c|c|c|c|c|}
\hline \multirow{2}{*}{ No } & \multirow[t]{2}{*}{ Nama Siswa } & \multicolumn{5}{|c|}{ Aspek Yang Dinilai } & \multirow{2}{*}{ Jml } & \multirow{2}{*}{ Nilai } & \multirow{2}{*}{ Ket } \\
\hline & & 1 & 2 & 3 & 4 & 5 & & & \\
\hline 1 & HW & 4 & 4 & 5 & 5 & 5 & 23 & 92 & SB \\
\hline 2 & FD & 5 & 4 & 5 & 5 & 4 & 23 & 92 & SB \\
\hline 3 & AA & 2 & 1 & 2 & 2 & 2 & 9 & 36 & SK \\
\hline 4 & GK & 5 & 5 & 5 & 5 & 5 & 25 & 100 & SB \\
\hline 5 & IA & 5 & 5 & 4 & 5 & 5 & 24 & 96 & SB \\
\hline 6 & $\mathrm{SH}$ & 5 & 4 & 5 & 5 & 5 & 24 & 96 & SB \\
\hline 7 & FU & 1 & 5 & 2 & 1 & 2 & 11 & 44 & SK \\
\hline 8 & WG & 2 & 1 & 2 & 2 & 1 & 8 & 32 & SK \\
\hline 9 & MF & 5 & 5 & 5 & 5 & 2 & 22 & 88 & SB \\
\hline 10 & NK & 5 & 1 & 4 & 5 & 4 & 19 & 76 & B \\
\hline 11 & AW & 5 & 4 & 5 & 5 & 5 & 24 & 96 & SB \\
\hline 12 & WM & 4 & 5 & 4 & 5 & 5 & 23 & 92 & SB \\
\hline 13 & FU & 5 & 5 & 5 & 5 & 3 & 23 & 92 & SB \\
\hline 14 & $\mathrm{AD}$ & 5 & 2 & 5 & 5 & 5 & 22 & 88 & SB \\
\hline 15 & AA & 5 & 2 & 4 & 5 & 5 & 22 & 88 & SB \\
\hline 16 & SF & 5 & 5 & 4 & 4 & 5 & 23 & 92 & SB \\
\hline 17 & RA & 3 & 4 & 4 & 5 & 5 & 21 & 84 & B \\
\hline 18 & AM & 5 & 2 & 5 & 5 & 4 & 21 & 84 & B \\
\hline 19 & MR & 5 & 1 & 5 & 5 & 4 & 20 & 80 & $\mathrm{~B}$ \\
\hline 20 & $\mathrm{IH}$ & 1 & 3 & 2 & 1 & 2 & 9 & 36 & SK \\
\hline 21 & DS & 4 & 2 & 1 & 1 & 5 & 13 & 52 & SK \\
\hline \multirow[t]{3}{*}{22} & $\mathrm{AH}$ & 5 & 5 & 5 & 5 & 5 & 25 & 100 & SB \\
\hline & Jumlah & 91 & 75 & 88 & 91 & 88 & 434 & 1.736 & \\
\hline & Rata-rata & 4,13 & 3,40 & 4 & 4,13 & 4 & 19,72 & 78.90 & \\
\hline
\end{tabular}

Dari uraian pada tabel 4.12 di atas, penilaian dari lima aspek dalam rubrik penilaian sebagai aspek penilaian analisis data pada tes awal : aspek 1) bagian-bagian yang ada dalam surat resmi, 2) kelengkapan dalam kepala surat resmi, 3) syarat penyusunan dalam membuat surat resmi, 4) kelengkapan dalam penutup surat resmi, 5) membuat surat resmi sesuai dengan struktur sistematika penulisan surat resmi yang baik dan benar. Meningkatkan keterampilan menulis surat resmi dengan menggunakan model pembelajaran inkuiri siswa kelas VII SMP Negeri 18 Tidore Kepulauan, dari hasil penilaian tersebut dapat diklasifikasikan analisis data hasil penelitian, bahwa pada tes akhir 18 siswa mampu menulis surat resmi dengan baik dan mencapai (KKM) sedangkan ada 5 siswa yang belum mampu menulis surat resmi dengan baik dan belum mencapai (KKM). 


\section{Pembahasan Hasil Penelitian}

Hasil Rekapitulasi Nilai Menulis Surat Resmi Siswa

Pada PreTest dan PostTest

\begin{tabular}{llcc}
\hline No & Nama Siswa & PreTest & PostTest \\
\hline 1 & HW & 36 & 92 \\
2 & FD & 48 & 92 \\
3 & AA & 40 & 36 \\
4 & GK & 96 & 100 \\
5 & IA & 28 & 96 \\
6 & SH & 48 & 96 \\
7 & FU & 40 & 44 \\
8 & WG & 32 & 32 \\
9 & MF & 48 & 88 \\
10 & NK & 44 & 76 \\
11 & AW & 96 & 96 \\
12 & WM & 92 & 92 \\
13 & FU & 40 & 92 \\
14 & AD & 40 & 88 \\
15 & AA & 40 & 88 \\
16 & SU & 96 & 92 \\
17 & RA & 48 & 84 \\
18 & AM & 32 & 84 \\
19 & MR & 36 & 80 \\
20 & IH & 40 & 36 \\
21 & DS & 32 & 52 \\
22 & AH & 92 & 100 \\
\hline & Jumlah & 1.144 & 1.736 \\
\hline & Rata-rata & 52 & 78.90 \\
\hline
\end{tabular}

Dari hasil tes awal kemampuan menulis surat resmi siswa kelas VII SMP Negeri 18 Tidore Kepulauan tidak menggunakan model pembelajaran inkuiri menunjukkan bahwa siswa masih belum tuntas mencapai (KKM) pada mata pelajaran Bahasa Indonesia dalam materi menulis surat resmi. Keseluruhan siswa berjumlah 22 orang dan yang mencapai ketuntasan berjumlah 5 siswa. Adapun yang tidak tuntas berjumlah 17 siswa bisa dilihat pada tabel di atas, sedangkan pada tes akhir sebagian besar siswa sudah bisa mencapai ketuntasan (KKM) dalam pembelajaran Bahasa Indonesia dengan materi menulis surat resmi menggunakan model pembelajaran inkuiri sudah bisa mencapai (KKM). Siswa yang mencapai ketuntasan berjumlah 17 siswa dan yang tidak tuntas berjumlah 5 siswa bisa dilihat pada tabel di atas bahwa siswa mampu menulis surat resmi dengan baik dan benar dengan menggunakan model pembelajaran inkuiri. Temuan penelitian ini sejalan dengan hasil penelitian yang dilakukan oleh Nurhasanah (2014) dan Alpiah \& Wikanengsih (2019) yang melakukan penelitian tentang pembelajaran menulis dengan menerapkan metode inkuiri menunjukkan terjadinya peningkatan menulis teks negoisasi seperti yang dilakukan oleh Nurhasanah dan peningkatan menulis puisi seperti yang dilakukan Alpiah. Sebagaimana pendapat yang dikemukakan Nurhadi (2003) bahwa proses pembelajaran dengan metode inkuiri ialah siswa dapat bekerja sesuai dengan 
permasalahan yang sama dan bahkan mereka bekerja sama mencari solusi terhadap masalah-masalah. Setiap siswa memainkan dan memfungsikan talentanya masingmasing.

\section{Simpulan}

Berdasarkan tabel rekapitulasi hasil penilaian dalam pembelajaran menulis surat resmi siswa kelas VII SMP Negeri 18 Tidore Kepulauan dengan menggunakan 5 aspek penilaian yang telah diuraiakan di atas. Nilai yang diperoleh siswa pada tes awal (PreTest) siswa belum mencapai peningkatan nilai dalam menulis surat resmi nilai yang dicapai 52, belum mencukupi KKM sekolah, sehingga peneliti akan melakukan penelitian lanjutan untuk meningkatkan nilai yang diperoleh siswa pada tes awal (PreTest).

Hasil tes akhir dapat disimpulkan bahwa para siswa mampu menulis surat resmi dengan menggunakan model pembelajaran inkuiri. Hal ini bisa dilihat pada tabel yaitu rekapitulasi hasil penilaian, siswa bisa memperoleh nilai yang maksimal karena sebagian besar siswa mampuh mencapai (KKM) yang telah ditetapkan pada SMP Negeri 18 Tidore Kepulauan dalam pembelajaran Bahasa Indonesia dengan materi menulis surat resmi dan siswa yang mencapai (KKM) berjumlah sebanyak 17 siswa sedangkan yang tidak mencapai (KKM) berjumlah sebanyak 5 siswa yang tidak tuntas.

\section{Ucapan Terima Kasih}

\section{Daftar Pustaka}

Alpiah, S., \& Wikanengsih, W. 2019. Penerapan metode inkuiri dalam pembelajaran menulis puisi siswa SMK. Parole Uurnal Pendidikan Bahasa Dan Sastra Indonesia), 2(2), 215-218.

Arikunto, S. 2013. Prosedur Penelitian Suatu Pendekatan Praktik. Edisi Revisi. Jakarta: PT. Rineka Cipta.

Gulo, W. 2005. Strategi Belajar Mengajar. Jakarta: Grasindo.

Hakim, M. N. 2016. Peningkatan Menulis Paragraf Melalui Penerapan Lesson Study Mahasiswa Semester 1B Program Studi Pendidikan Bahasa dan Sastra Indonesia. Prosiding, 2(1).

Nanik, Dkk. 2014. Korespondensi Bahasa Indonesia.Yogyakarta: Graha Ilmu.

Nurhasanah, D. 2014. Penerapan Metode Inkuiri dalam Pembelajaran Menulis Teks Negosiasi: Penelitian Eksperimen Semu pada Siswa Kelas X di SMA Negeri 7 Bandung Tahun Ajaran 2013/2014 (Doctoral dissertation, Universitas Pendidikan Indonesia).

Nurhadi,dkk. 2004. Pembelajaran Kontekstual dan Penerapannya dalam KBK. Malang: UM Press. 
ISSN 2443-3667 (print) 2715-4564 (online)

Sugiartanti, S. 2020. Peningkatan Prestasi Belajar Menulis Teks Berita Melalui Model Pembelajaran Inkuiri Dengan Media Foto Pada Siswa Kelas Viii-F Smp Negeri 1 Benjeng Gresik Tahun Pelajaran 2017/2018. e-Jurnal Mitra Pendidikan, 4(12), 812-822.

Suyatno. 2007. Aneka Model Pembelajaran Bahasa Indonesia. Surabaya : University Press.

Syahfitri, D. 2018. Penggunaan Metode Inkuiri Terhadap Peningkatan Keterampilan Menulis Surat Resmi Pada Siswa Smp Negeri 1 Padangsidimpuan. Jurnal $L P P M, 9(1 \mathrm{C}), 7-13$.

Tarigan, H. G. 2000. Teknik Menulis. Bandung: Angkasa. 